Notes and Comments

\title{
First Report of Leptocybe invasa Fischer \& LaSalle (Hymenoptera: Eulophidae) in the southern Tocantins, Brazil
}

\author{
R. A. Sarmento ${ }^{\mathrm{a} *}$ (1), M. I. Sarmento ${ }^{\mathrm{a}}$ (ㅇ, R. S. da Silva ${ }^{\mathrm{b}}$ (1) and R. Afonso ${ }^{\mathrm{a}}$ (1) \\ a Universidade Federal do Tocantins - UFT, Programa de Pós-graduação em Ciências Florestais e Ambientais, Gurupi, TO, Brasil

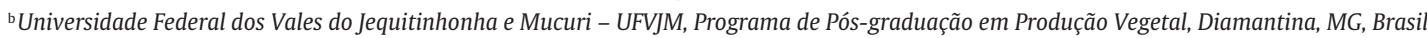

The eucalyptus gall wasp, Leptocybe invasa Fischer \& LaSalle (Hymenoptera: Eulophidae), causes severe damage to susceptible plants of the genera Eucalyptus L'Hér. and Corymbia K.D. Hill \& L.A.S. Johnson, in which it induces galls in the midribs and petioles of young leaves and in the internodes of branch apices. Even though the insect attacks trees of all ages, the infestations are generally more severe in nursery seedlings and young plantations ( $1-3$ years old) than in older plantations (Wylie and Speight 2012), and the wasp is more often found in warmer and drier zones than in colder and wetter zones (Nyeko et al., 2009).

The eucalyptus gall wasp spread quickly for plantations of Eucalyptus in nurseries and forest areas. The pest (Mendel et al., 2004, Nyeko et al., 2009) was first reported in northeast Brazil in 2008 (Wilcken and Berti-Filho 2008), and is currently distributed throughout America, Africa, Asia, the
Middle East, and Europe. This study aimed to report the presence of $L$. invasa in southern Tocantins state within central Brazil.

The pest was first observed infesting plants in a commercial plantation of Eucalyptus clones (VS058) from the crossbreeding of Eucalyptus tereticornis Sm. × Eucalyptus camaldulensis Dehnh., located in the municipality of Peixe, Tocantins (12.052696 ${ }^{\circ}$, $48.550525^{\circ} \mathrm{W}$ ). This initial infestation was detected in an area of $180 \mathrm{ha}$, where it spreaded quickly to neighboring plantations, reaching an area of 3000 ha planted with clones from the crossbreeding mentioned above. After detection in the field, the wasp attack was also found in clonal rooted cuttings of Eucalyptus clones from this same crossbreeding. With an infestation intensity of up to 30 galls per plant branch, the galls were first observed on the midribs and petioles of leaves with young buds, and the emergence holes dug by the adult insects were observed in plant branches approximately six months old (Figure 1).After detecting the wasp attacking young plants,
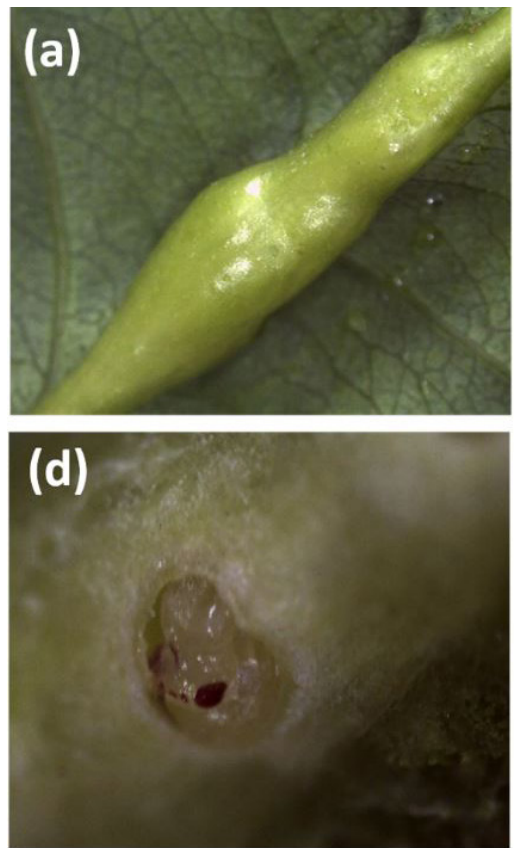

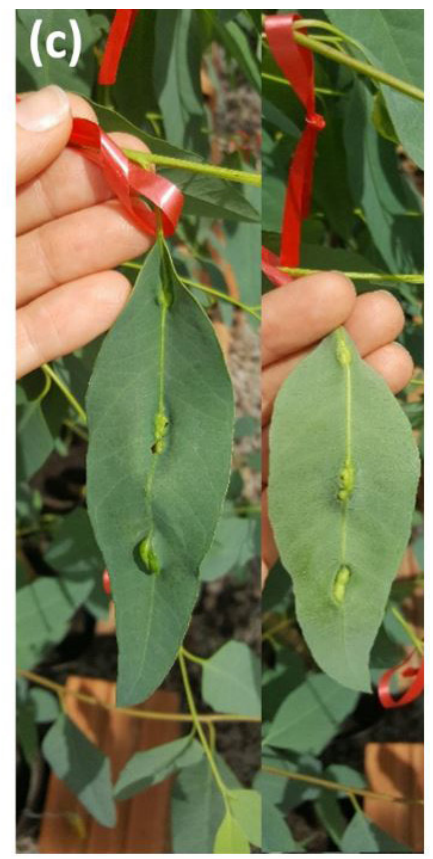

Figure 1. Figures $a$ and $b$ illustrate a midrib gall (a) and a petiole gall (b), leaves with galls along the midrib - adaxial and abaxial surfaces (c), exit hole of adult insect (d) and L. invasa adult (e).

*e-mail: rsarmento@uft.edu.br

Received: June 25, 2020 - Accepted: October 21, 2020

This is an Open Access article distributed under the terms of the Creative Commons Attribution License, which permits unrestricted use, distribution, and reproduction in any medium, provided the original work is properly cited. 
even in the field, or in clonal rooted cuttings, the wasp was also found attacking old plants with the same infestation intensity mentioned above. Emerging adult wasps were sent to Professor Carlos Frederico Wilcken (Faculty of Agronomic Sciences, Paulista State University, Botucatu Campus). The specimens were confirmed as L. invasa, according to the description of Mendel et al. (2004). Thus, the pest was first reported from central Brazil, in the southern Tocantins state.

This report remarks on the importance of carrying out sanitary inspection programs of the L. invasa in central Brazil and provided information on its new occurrence to facilitate the research regarding control strategies.

\section{Acknowledgements}

The authors are grateful to Professor Carlos Frederico Wilcken for identifying the insect, Jéssica Bandeira for preparing the map, the Coordination for the Improvement of Higher Education Personnel (CAPES - PROCAD 2013) and the National Council for Scientific and Technological Development (CNPq) for supporting the experiments conducted in Gurupi (Project 422832/2018-9), TO, Brazil. Funding: R.A.S. received a research grant from Conselho Nacional de Desenvolvimento Científico e Tecnológico (306652/2018-8).

\section{References}

MENDEL, Z., PROTASOV, A., FISHER, N. and LA SALLE, J., 2004. Taxonomy and biology of Leptocybe invasa gen. \& sp. n. (Hymenoptera: Eulophidae), an invasive gall inducer on Eucalyptus. Austral Entomology, vol. 43, no. 2, pp. 101-113. http://dx.doi.org/10.1111/j.1440-6055.2003.00393.x.

NYEKO, P., MUTITU, E.K. and DAY, R.K., 2009. Eucalyptus infestation by Leptocybe invasa in Uganda. African Journal of Ecology, vol. 47, no. 3, pp. 299-307. http://dx.doi.org/10.1111/j.13652028.2008.01004.x.

WILCKEN, C. F., and BERTI-FILHO, E., 2008. Vespa-da-galha do eucalipto (Leptocybe invasa) (Hymenoptera: Eulophidae): nova praga de florestas de eucalipto no Brasil. Alerta IPEF, 1-11.

WYLIE, F.R. and SPEIGHT, M.R., 2012. Insect pests in tropical forestry. England: CABI. http://dx.doi.org/10.1079/9781845936365.0000. 